\title{
Genetic evidence for mixed modes of reproduction in the coral Pocillopora damicornis and its effect on population structure
}

\author{
Kelley Whitaker* \\ Department of Zoology, The University of Western Australia, Nedlands, Western Australia 6907, Australia \\ Present address: Department of Genetics, University of Pretoria, Pretoria 0002, South Africa
}

\begin{abstract}
Allozyme electrophoresis of 6 polymorphic loci was used to estimate the relative importance of sexual and asexual reproduction in Western Australian populations of the coral Pocillopora damicornis and to infer the extent of larval dispersal between them. Evidence for considerable yet variable amounts of asexual reproduction was found. Only 96 of a total of 644 coral heads sampled were apparently of sexual origin, and 8 of the 10 populations showed large departures from HardyWeinberg equilibria as a result of both heterozygote excesses and deficits. Multi-locus genotypic diversity values were significantly less than expected for 8 of the 10 populations sampled, but the magnitude of these values varied enormously (range $G_{0}: G_{\mathrm{e}}=0.072$ to 0.770 ). Significant genetic subdivision among populations was found $\left(F_{\mathrm{ST}}=0.360\right)$ that was not attributable to different reefs $\left(F_{\mathrm{RT}}=\right.$ $0.080)$, habitat type $\left(F_{\mathrm{HT}}=-0.039\right)$, or geographical distance between populations (Mantel test $\mathrm{p}=$ 0.129). However, pairwise comparisons revealed significant genetic subdivision at all spatial scales sampled. Furthermore, this subdivision was largely maintained even among populations of putative sexual origin $\left(F_{\mathrm{ST}}=0.175\right)$. These results are consistent with the notion that reefs at Ningaloo and the Houtman Abrolhos Islands are primarily self-seeding and that asexually derived recruits have a considerable effect on local abundance and population structure.
\end{abstract}

KEY WORDS: Clonal reproduction · Population structure $\cdot$ Genotypic diversity $\cdot$ Coral reef $\cdot$ Gene flow $\cdot$ Larval dispersal

\section{INTRODUCTION}

Whether coral reefs are primarily self-seeding or interdependent for larval recruits is still a hotly debated question. Many scleractinians have broad geographic distributions (Veron 1995), and so must be capable of transoceanic dispersal, at least occasionally. Since direct observations of planktonic larval dispersal are difficult, larval development and duration in the plankton are thought to be important predictors of dispersal capability. Larvae that are brooded following internal fertilisation are generally well developed on release and competent to settle within a few hours or days (Harrison \& Wallace 1990). Conversely, larvae from broadcast spawners undergo fertilisation, larval development and maturation in the water column, and are competent to settle from at least $4 \mathrm{~d}$ but with competency peaking 7 to $10 \mathrm{~d}$ after release (Harrison et al. 1984, Baird 2001). Increased competency periods and recruitment patterns presumably driven by largescale hydrodynamic or meterological phenomena are thought to favour, on average, the dispersal of broadcasters over greater geographic distances compared to their brooded counterparts (Harrison et al. 1984, Hughes et al. 1999, Baird 2001). Comparative studies of brooding and broadcasting invertebrates including corals, sampled over the same spatial scales, indicate that in general broadcast spawners typically have 
lower levels of genetic differentiation than brooders, which is consistent with the notion of dispersal over greater distances (Duffy 1993, Hunt 1993, Hellberg 1996, Ayre et al. 1997b, Whitaker 1997, 2004; for broader reviews on this topic see, e.g., Bohonak 1999).

Observations that the vast majority of scleractinian corals are broadcasters, together with studies of water movement and flushing times of reefs in the Great Barrier Reef system (Williams et al. 1984), studies of larval development and pre-competency times (Babcock \& Heyward 1986) and tracking of coral spawn slicks (Willis \& Oliver 1988) have supported the view that dispersal is widespread and reefs are inter-connected for larval supply. Fuelling this debate are studies of coral community assemblages (Done 1982) and recruitment (Bak \& Engel 1979, Sammarco \& Andrews 1988), simulations of oceanographic processes (Black et al. 1990, Black 1993) and, more recently, population genetic studies (Whitaker 1997, 2004, Ayre \& Hughes 2000, 2004, Miller \& Ayre 2004) that support the view that reefs are primarily self-seeding. An important difference between these 2 views is that support for the connectedness of reefs is based largely on studies of sexually produced propagules, whereas studies of community assemblages, recruitment and population genetics include individuals potentially derived through both asexual and sexual reproduction. Asexual reproduction is commonly regarded as important for local proliferation, whereas sexually derived propagules are thought to be important for larger-scale dispersal. Population genetic studies provide a perspective that is advantageous over other studies, particularly for longlived species, since they reflect the historical average of dispersal and successful recolonisation events, and can be partitioned to examine the relative contribution of sexual and asexual recruitment. Asexual recruitment into a population may occur either through clonal production of larvae (e.g. Stoddart 1983) or colony fragmentation (e.g. Highsmith 1982).

The dispersal debate was brought sharply into focus following severe declines in coral cover at Ningaloo Reef, a fringing/barrier reef extending $280 \mathrm{~km}$ off the north-western Australian coast, between $21^{\circ} 50^{\prime} \mathrm{S}$ and $23^{\circ} 35^{\prime} \mathrm{S}$. Due to precipitous increases in the numbers of the corallivorous gastropod Drupella cornus, $75 \%$ of coral cover from the backreef was lost in the late 1980s and early 1990s (Stoddart 1989, Forde 1994). Corals of the families Acroporidae, Pocilloporidae and Poritidae were most affected (Forde 1994, A. M. Ayling \& A. L. Ayling unpubl.). Recolonisation and recovery of vacant reef patches will depend on the successful dispersal and settlement, growth and survival of larval propagules or fragments. Understanding the extent of dispersal both within and between reefs is important, not only for understanding evolutionary processes and population dynamics, but also for the conservation and management of coral reefs.

The aim of the present study was to examine patterns of genetic variation among collections of Pocillopora damicornis (Pocilloporidae) from Western Australia, to infer both the extent of genetic mixing within and between reefs and the relative importance of recruits derived from sexual and asexual reproduction. P. damicornis is a useful species to test ideas about the extent of genetic connectivity of coral reefs. It is an effective coloniser of vacant reef habitats and is ubiquitous on reefs throughout the Indo-Pacific, including Hawaii (Veron 1986), so it must be capable of dispersing across oceanic boundaries, at least occasionally. Larval development may be internal with brooding of asexual planulae (Stoddart 1984a), or external via broadcast spawning of gametes (Ward 1992, Glynn et al. 1991), but the relative importance of these modes of reproduction is known to vary across its range. Populations in southwestern Australia, Panama, Hawaii and the Ryukyu Islands are maintained by both sexually and asexually derived recruits (Stoddart 1984a, Richmond 1987, Adjeroud \& Tsuchiya 1999). In contrast, on the Great Barrier Reef and Lord Howe Island reefs, patterns of genetic variation are consistent with sexual reproduction as the primary mode of reproduction (Benzie et al. 1995, Ayre et al. 1997a, Ayre \& Hughes 2004, Miller \& Ayre 2004, though see Ayre \& Miller 2004).

\section{MATERIALS AND METHODS}

Samples. Samples of Pocillopora damicornis from each of 8 sites on Ningaloo Reef and 2 sites in the Houtman Abrolhos Islands were collected between August 1991 and April 1993 (Fig. 1). They were collected from backreef and lagoonal habitats, at a depth of $<5 \mathrm{~m}$ (see Table 1). It was not always possible to sample within the same habitat because of the nature of the coral loss following Drupella cornus predation. Corals were collected following a haphazard design. Branches from individual coral heads were broken off when encountered, irrespective of the distance between adjacent samples, provided there was clear demarcation between coral heads. Specimens collected were taken from coral heads of a similar size, approximately 20 to $25 \mathrm{~cm}$ in diameter, and the area sampled was approximately $50 \times 50 \mathrm{~m}$. Corals of this size would have recruited into the population before the D. cornus outbreaks. Assuming population sizes were still relatively large at the time of collection and that predation by $D$. cornus was random with respect to genotype, it is unlikely that the populations sampled were out of equilibrium because of $D$. cornus predation. 


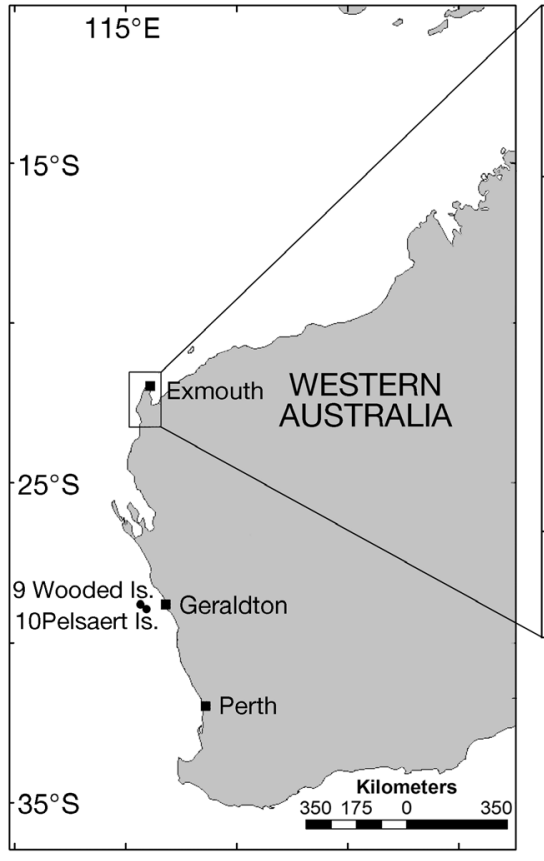

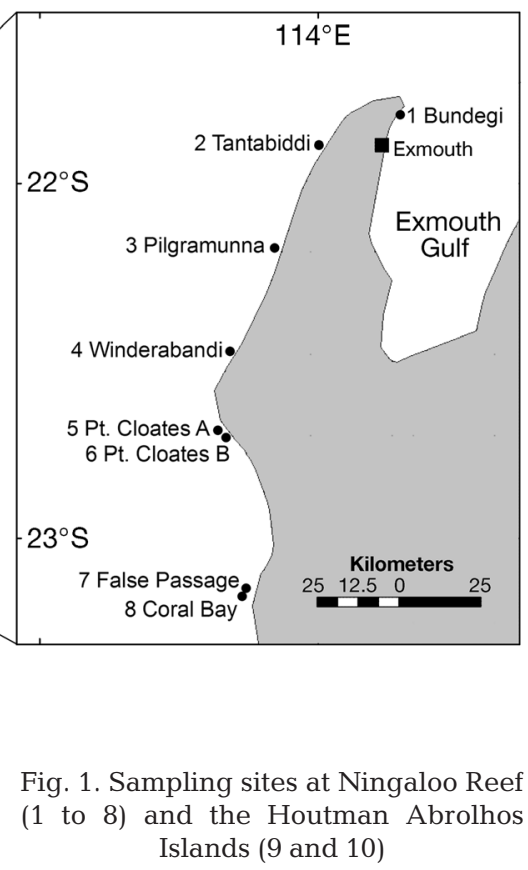

Six consistently scorable polymorphic loci were found after preliminary screening of 30 enzymes encoding 37 loci on 6 buffer systems. They were Gpi (glucose-6-phosphate isomerase E.C. 5.3.1.9) and Ark (arginine kinase E.C. 2.7.3.3) on TC8, Mpi (mannose-6-phosphate isomerase E.C. 5.3.1.8) on TEB and Pgm (phosphoglucomutase E.C. 5.4.2.2), Mdh-1 and Mdh-2 (malate dehydrogenase E.C. 1.1.1.37) on TM. Recipes for staining these enzymes were similar to those in Richardson et al. (1986). Because the activity of the enzymes being assayed was sometimes low, concentrations of the substrate, cofactor, linking enzymes and dye were increased as much as 4 times. Different loci encoding the same type of enzyme were numbered in order of decreasing mobility. For example, allozymes of Mdh-1 migrated faster than those of Mdh-2. Similarly, alleles at each locus were labelled

To minimise potential problems of phenotypic plasticity, interspecies hybridisation and cryptic species, collections of Pocillopora damicornis included only those phenotypes that could be consistently recognised at the species level. Very rarely $(<1 \%)$ colonies with more elongate and fragile branching morphologies were encountered. These were not sampled to avoid problems of sampling potential hybrids (e.g. Miller \& Ayre 2004). In addition, only the growing tips were used for genetic analysis. The tips are the most metabolically active regions, contain no reproductive products and are not likely to be fused with other corals (Heyward \& Stoddart 1985, Wallace 1985, Harrison \& Wallace 1990). The extent of each coral colony or head was easily identifiable. Growing tips were broken off each head, placed in zip-lock plastic bags and held in seawater prior to freezing in liquid nitrogen. The maximum holding time before freezing was $2 \mathrm{~h}$. Once in the laboratory, samples were held at $-70^{\circ} \mathrm{C}$ pending allozyme electrophoresis.

Allozyme electrophoresis. Enzymes were extracted by homogenising 1 vol of coral tissue, including skeleton, in $1.5 \mathrm{vol}$ of $10 \%(\mathrm{w} / \mathrm{v})$ sucrose containing $1 \%$ (v/v) mercaptoethanol and $0.1 \%$ (w/v) bromophenol blue. Electrophoresis was carried out using horizontal starch gels with a tris citrate (TC8), trisEDTA-borate (TEB), or tris-maleate (TM) buffer (Buffers 5, 6 and 9, respectively, of Selander et al. 1971).
Table 1. Pocillopora damicornis. Departures from Hardy-Weinberg equilibria at Ningaloo Reef (Sites 1 to 8) and the Houtman Abrolhos Islands (Sites 9 and 10), expressed as Wright's (1951) $F_{\text {IS }}$. Negative values indicate an excess of heterozygotes, and positive values, a deficit of heterozygotes. n: sample size; L: lagoonal habitat; B: backreef habitat. ${ }^{*} \mathrm{p}<0.05{ }^{* *} \mathrm{p}<0.01{ }^{* * *} \mathrm{p}<0.001$ after Bonferroni correction

\begin{tabular}{|c|c|c|c|c|c|c|c|}
\hline \multirow{2}{*}{ Site } & \multirow{2}{*}{$\mathrm{n}$} & \multicolumn{6}{|c|}{ Loci } \\
\hline & & Ark & Gpi & $M d h-1$ & Mdh-2 & Mpi & Pgm \\
\hline $1(\mathrm{~L})$ & 101 & $-0.059^{* * *}$ & $0.122^{* * *}$ & -0.104 & (1 allele) & 0.058 & $0.904^{* * *}$ \\
\hline $2(\mathrm{~L})$ & 77 & -0.078 & $0.373^{* *}$ & (1 allele) & $0.557^{*}$ & $0.685^{* * *}$ & $0.759^{* * *}$ \\
\hline 3 (B) & 56 & 0.075 & 0.691 & (1 allele) & 0.897 & (1 allele) & -0.362 \\
\hline 4 (B) & 109 & $-0.516^{* * *}$ & $-0.330^{* * *}$ & 0.924 & 0.924 & $0.012^{* * *}$ & $0.401^{* * *}$ \\
\hline 5 (B) & 85 & $-0.448^{* * *}$ & 0.853 & (1 allele) & $0.826^{*}$ & 0.030 & $1.000^{*}$ \\
\hline 6 (B) & 50 & $-0.550^{* *}$ & 0.344 & (1 allele) & 0.744 & $0.744^{* * *}$ & $0.675^{* * *}$ \\
\hline 7 (L) & 20 & (1 allele) & -0.466 & (1 allele) & (1 allele) & 0.235 & $-0.052^{* * *}$ \\
\hline 8 (B) & 20 & 0.0548 & -0.136 & (1 allele) & (1 allele) & 1.000 & 1.000 \\
\hline 9 (L) & 27 & -0.264 & 0.579 & (1 allele) & (1 allele) & $0.735^{*}$ & (1 allele) \\
\hline $10(\mathrm{~L})$ & 99 & (1 allele) & -0.037 & (1 allele) & (1 allele) & $-0.347^{* * *}$ & (1 allele) \\
\hline
\end{tabular}


Tests for linkage disequilibrium between pairs of loci were based on 100000 permutations using the programme Arlequin (Schneider et al. 2000).

Two measures were used to estimate the extent of asexual reproduction using multi-locus analyses. First, the maximum proportion of a sample that could have been generated through sexual reproduction $\left(N^{*}: N_{\mathrm{i}}\right)$ was calculated using a modification of the method of Johnson \& Threlfall (1987), as described by Whitaker (2004). This method assumes panmixia within samples, but not between. Second, the observed multi-locus genotypic diversity $\left(G_{0}\right)$ was compared to that expected $\left(G_{\mathrm{e}}\right)$ under conditions of panmixia following the method of Stoddart \& Taylor (1988). $G_{\mathrm{o}}$ incorporates an estimate of both genotypic diversity or richness (the number of unique multi-locus genotypes) and the relative abundance (evenness) of genotypes (Coffroth \& Lasker 1998). Since $N_{\mathrm{c}}$ (the number of unique multilocus genotypes in a sample) is an estimate of multilocus genotypic richness, then genotypic evenness or the number of individuals per clone (or ramets) can be estimated by the ratio $G_{\mathrm{o}}: N_{\mathrm{c}}$ (Coffroth \& Lasker 1998). Evenness reaches a maximum value of 1 when all multi-locus genotypes are distributed evenly.

As a measure of the genotypic similarity between pairs of samples, the proportion of genotypes shared between samples was calculated using Stoddart's (1984b) formula:

$$
N_{\mathrm{cS}}=\frac{2 N_{\mathrm{ab}}}{N_{\mathrm{a}}+N_{\mathrm{b}}}
$$

where $N_{\mathrm{a}}$ and $N_{\mathrm{b}}$ are the number of genotypes in Samples a and b, respectively, and $N_{\mathrm{ab}}$ is the number of genotypes common to both samples.

Allelic variation: Two hierarchical tests of genetic differentiation were calculated using the programme Arlequin (Schneider et al. 2000): among habitats (backreef and lagoon) and among reefs (Ningaloo and Abrolhos Islands). Significance tests for each of the variance components were done following the methods of Excoffier et al. (1992), using 100000 permutations, and a distance matrix that assumes all alleles are equidistant. Under this assumption the analysis is equivalent to the multiallelic analysis of variance of Weir \& Cockerham (1984) (Excoffier et al. 1992). Because only lagoonal samples were collected from the Houtman Abrolhos Islands, the potential for confounding effects of habitat type and reef existed. To test for potential confounding effects prior to conducting the hierarchical tests, I first checked for a habitat type effect within Ningaloo and for reef effects within the lagoonal habitat. $F_{\mathrm{ST}}$ values for both these tests were not statistically significant $\left(F_{\mathrm{ST}}=-0.02, \mathrm{p}=0.465\right.$ and $\left.F_{\mathrm{ST}}=0.096, \mathrm{p}=0.300\right)$. Hierarchical $F$ statistics were performed on 2 data sets: the first included all individ- uals irrespective of reproductive origin. The second included only those individuals with a unique multilocus genotype within that sample and represented individuals of sexual origin.

Differentiation tests between all pairs of samples were done using a Markov chain with a branch length of 100000 steps using the programme Arlequin (Schneider et al. 2000). The Mantel test in Arlequin was used to test for isolation-by-distance effects also using 100000 permutations. These tests were repeated following removal of replicate multi-locus genotypes from all samples.

Bonferroni corrections were done following multiple tests (Rice 1989).

\section{RESULTS}

\section{Single-locus genotypic variation}

There was enormous variation in the goodness-of-fit to Hardy-Weinberg expectations; only genotypic frequencies from 2 of the 10 collections (Sites 3 and 8) were not significantly different from Hardy-Weinberg expectations (Table 1). Of a possible 42 tests, 20 showed significant deviations from Hardy-Weinberg proportions, considerably more than expected by chance alone. Seven of these showed heterozygote excesses, while the remaining 13 showed heterozygote deficits. All samples had both excesses and deficits of heterozygotes over the 6 loci, with the exception of Site 10, which had only excesses of heterozygotes (Table 1). Strong associations between loci were found with 14 of 15 locus pairs in linkage disequilibrium (Table 2). Sites 1 and 4 were found to be in disequilibria for 10 of these. Disequilibrium among locus pairs at the remaining sites was variable (Table 2).

\section{Multi-locus genotypic variation}

A total of 644 coral heads was sampled, but this represented only 96 unique multi-locus genotypes. Because only a small portion of the total expressed proteins was sampled electrophoretically, replicate multi-locus genotypes may arise through asexual or sexual reproduction. The ratio $N^{*}: N_{\mathrm{i}}$ is an estimate of the maximum proportion of the sample that could have been generated through sexual reproduction assuming equilibrium conditions within samples, but not necessarily between them. This varied considerably between sites, from a low of $41 \%$ at Site 10 to a maximum of $100 \%$ at Site 2 (Table 3). Similarly, the relative importance of asexual to sexual reproduction, as measured by the ratio of observed to expected levels of multi-locus genotypic diver- 
sity, varied enormously between sites. Only Sites 3 and 8 showed levels of genotypic diversity similar to those expected under conditions of sexual reproduction $\left(G_{\mathrm{o}}: G_{\mathrm{e}}=\right.$ 0.770 and $G_{\mathrm{o}}: G_{\mathrm{e}}=0.725$, respectively, Table 3 ). These sites were also the only ones in Hardy-Weinberg equilibrium. Those sites that showed significantly less multilocus genotypic diversity than expected varied in the extent of departure from unity, implying variation in the impact of asexual reproduction. Sites 1 and 4 showed very little multi-locus genotypic diversity $\left(G_{0}: G_{\mathrm{e}}=0.073\right.$ and 0.072 , respectively $)$ compared with Site $10\left(G_{\mathrm{o}}: G_{\mathrm{e}}=\right.$ 0.678 ) (Table 3 ). Evenness values were generally low but variable, ranging from 0.160 at Site 4 to 0.610 at Site 8 (Table 3), with only a few genotypes making up the majority of the sample at each site. For example, at Site 1, 41 specimens had the same multi-locus genotype, but the number of remaining replicate multi-locus genotypes did not exceed 7.

The proportion of genotypes shared between pairs of samples was extremely variable, ranging from 0 to $67 \%$. This was not attributable to distance between sites; some samples relatively close together shared few genotypes, whereas other samples several orders of magnitude further apart shared over half their genotypes (Fig. 2). Samples from the Houtman Abrolhos Islands shared just as many genotypes with Ningaloo as did samples within Ningaloo. However, Bundegi (Site 1) shared $<10 \%$ of its genotypes with other sites at Ningaloo and none with sites in the Houtman Abrolhos Islands (Fig. 2).

To assess whether samples of putative sexual origin conformed to equilibrium conditions, replicate multi-locus genotypes were removed from the data set and single locus genotypic proportions were re-analysed. Of the 10 samples, 6 (Sites 3, 5, 7, 8, 9, 10) conformed to Hardy-Weinberg proportions after Bonferroni corrections. The remaining samples showed, on average, significant deficits of heterozygotes.

\section{Allelic variation}

Allele frequencies differed widely among samples at most loci. The most striking difference among samples was at the Ark locus where the common allele $(c)$ was fixed at Site 7 , but was absent at Site 10 (Table 4). Hierarchical analyses of molecular variance revealed a high level of genetic subdivision among samples with an average $F_{\text {ST }}$ value of 0.360 (Table 5). There were no significant differences among reefs $\left(F_{\mathrm{RT}}=0.080\right)$ or habitats $\left(F_{\mathrm{HT}}=-0.039\right)$ (Table 5).
Table 2. Pocillopora damicornis. Tests for linkage disequilibrium between each locus pair. Numbers indicate sites where linkage disequilibrium was significant at $p<0.05$ after Bonferroni corrections

\begin{tabular}{|lc|}
\hline Locus pair & Site \\
\hline Ark-1/Gpi-1 & $1,4,9$ \\
Ark-1/Mdh-1 & 1 \\
Ark-1/Mdh-2 & 2 \\
Ark-1/Mpi-1 & $1,4,5,9$ \\
Ark-1/Pgm-1 & $1,2,3,4$ \\
Gpi-1/Mdh-1 & 1 \\
Gpi-1/Mdh-2 & 3,4 \\
Gpi-1/Mpi-1 & $1,4,6,7,9,10$ \\
Gpi-1/Pgm-1 & $1,4,6,7$ \\
Mdh-1/Mdh-2 & 4 \\
Mdh-1/Mpi-1 & 1,4 \\
Mdh-1/Pgm-1 & 1 \\
Mdh-2/Mpi & 4 \\
Mpi-1/Pgm-1 & $1,2,4,5,6,7,8$ \\
\hline
\end{tabular}

Differences among pairs of samples were quantified using pairwise $F_{\mathrm{ST}}$ comparisons. $F_{\mathrm{ST}}$ values between pairs of samples were all statistically significant, but varied enormously, from 0.023 to 0.582 (Fig. 3). Genetic divergence between pairs of samples was not a function of distance at the scale sampled (Mantel test $p=0.129)$. Samples that were $<30 \mathrm{~km}$ apart were as different as those $>800 \mathrm{~km}$ apart (Fig. 3, •).

Asexual reproduction may enhance measures of population differentiation, especially if clonal composition varies spatially. The level of population subdivision among samples of sexual origin was determined by first removing replicate multi-locus genotypes from the data set. Reduced, but significant, genetic differences were

Table 3. Pocillopora damicornis. Indices of genotypic diversity. $\left(N_{\mathrm{i}}\right.$ : number of individuals in a sample; $N_{\mathrm{c}}$ : number of unique multi-locus genotypes in a sample; $N^{*}$ : estimate of the maximum number of unique multi-locus genotypes in a sample, assuming panmixia; $N^{*}: N_{\mathrm{i}}$ : estimated maximum proportion of the sample generated by sexual reproduction; $G_{0}$ : observed multi-locus genotypic diversity; $G_{\mathrm{e}}$ : expected multi-locus genotypic diversity under conditions of sexual reproduction and free recombination; $G_{\mathrm{o}}: G_{\mathrm{e}}$ : measure of the relative importance of sexual and asexual reproduction; $G_{\mathrm{o}}: N_{\mathrm{c}}:$ measure of the evenness of the distribution of multi-locus genotypes within a sample; ${ }^{*} \mathrm{p}<0.05$; ${ }^{* *} \mathrm{p}<0.01 ;{ }^{* * *} \mathrm{p}<0.001$ after Bonferroni corrections

\begin{tabular}{|lccccrrll|}
\hline Site & $N_{\mathrm{i}}$ & $N_{\mathrm{c}}$ & $N^{*}$ & $N^{*}: N_{\mathrm{i}}$ & $G_{\mathrm{o}}$ & \multicolumn{1}{c|}{$G_{\mathrm{e}}$} & \multicolumn{1}{l}{$G_{\mathrm{o}}: G_{\mathrm{e}}$} & $G_{\mathrm{o}}: N_{\mathrm{c}}$ \\
\hline 1 & 101 & 28 & 53 & 0.525 & 5.39 & 73.67 & $0.073^{* * *}$ & 0.195 \\
2 & 71 & 30 & 71 & 1.000 & 10.57 & 20.56 & $0.514^{*}$ & 0.352 \\
3 & 56 & 11 & 54 & 0.964 & 4.72 & 6.13 & 0.770 & 0.429 \\
4 & 109 & 26 & 51 & 0.468 & 4.15 & 57.79 & $0.072^{* * *}$ & 0.160 \\
5 & 84 & 12 & 76 & 0.905 & 3.50 & 6.48 & $0.542^{* * *}$ & 0.292 \\
6 & 50 & 12 & 39 & 0.780 & 3.35 & 11.90 & $0.282^{* * *}$ & 0.279 \\
7 & 20 & 7 & 15 & 0.750 & 4.00 & 16.81 & $0.238^{* * *}$ & 0.571 \\
8 & 20 & 8 & 15 & 0.750 & 4.88 & 6.73 & 0.725 & 0.610 \\
9 & 27 & 9 & 23 & 0.852 & 4.47 & 8.39 & $0.533^{*}$ & 0.497 \\
10 & 98 & 5 & 40 & 0.408 & 1.96 & 2.89 & $0.678^{* * *}$ & 0.392 \\
\hline
\end{tabular}




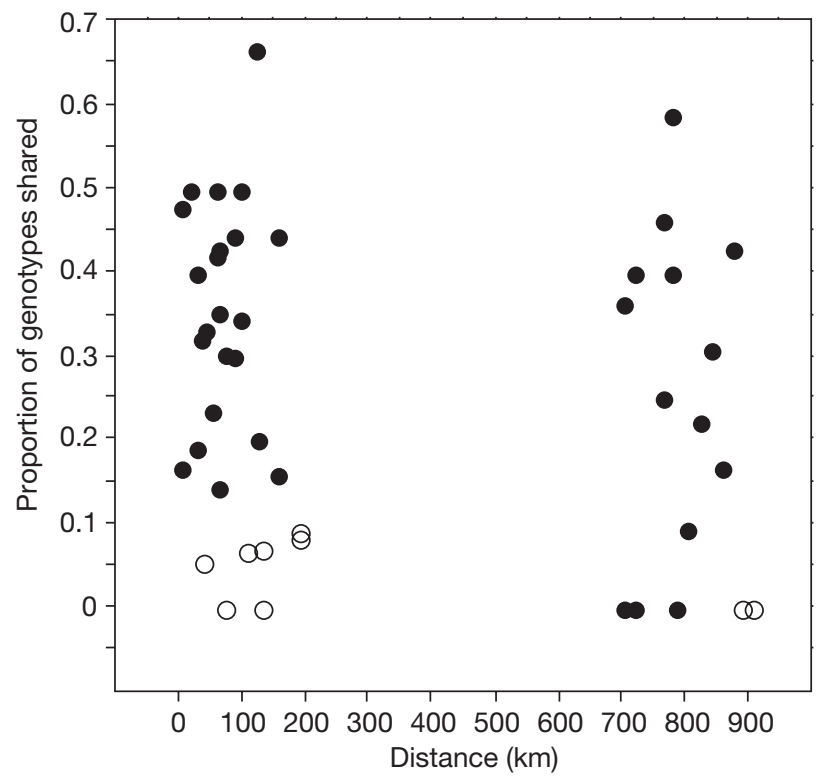

Fig. 2. Pocillopora damicornis. Proportion of genotypes shared between samples ( O: including Bundegi samples) found among pairwise comparisons of samples of apparent sexual origin, with an average $F_{\mathrm{ST}}$ value of 0.175 (Table 5). Once again, there was no association with distance (Fig. 3, o, Mantel test $p=0.130$ ) or habitat type, but there was a small difference between Ningaloo Reef and the Abrolhos Islands (Table 5). This may have been due to the combination of small sample sizes at the Houtmans Abrolhos Islands as well as unequal numbers of samples from these 2 reefs. However, I detected no significant difference among reefs using just 2 randomly chosen Ningaloo Reef samples (Sites 4 and 8 ) and those from the Houtman Abrolhos Islands $(p=0.332)$.

\section{DISCUSSION}

\section{Modes of reproduction}

These results indicate that populations of Pocillopora damicornis at Ningaloo Reef and the Houtman Abrolhos Islands have dual modes of reproduction, but that there is considerable variation in the relative contribu-

Table 4. Pocillopora damicornis. Allele frequencies at Ningaloo Reef (Sites 1 to 8) and the Houtman Abrolhos Islands (Sites 9 and 10), Western Australia

\begin{tabular}{|c|c|c|c|c|c|c|c|c|c|c|}
\hline \multirow{3}{*}{$\begin{array}{l}\text { Sites } \\
\text { (n) }\end{array}$} & \multicolumn{8}{|c|}{ Ningaloo Reef } & \multicolumn{2}{|c|}{ Abrolhos Islands } \\
\hline & 1 & 2 & 3 & 4 & 5 & 6 & 7 & 8 & 9 & 10 \\
\hline & 101 & 71 & 56 & 109 & 84 & 50 & 20 & 20 & 27 & 98 \\
\hline \multicolumn{11}{|l|}{ Ark } \\
\hline$a$ & 0.282 & - & - & - & - & - & - & - & - & - \\
\hline$b$ & 0.104 & 0.613 & 0.625 & 0.610 & 0.482 & 0.530 & 1.000 & 0.250 & 0.315 & - \\
\hline$C$ & 0.614 & 0.387 & 0.375 & 0.390 & 0.518 & 0.470 & - & 0.750 & 0.685 & 1.000 \\
\hline \multicolumn{11}{|l|}{ Gpi } \\
\hline a & 0.287 & - & - & - & - & - & - & - & - & - \\
\hline$b$ & - & 0.035 & - & 0.353 & - & 0.040 & 0.375 & - & - & - \\
\hline C & - & - & 0.036 & 0.009 & - & - & - & - & - & - \\
\hline$d$ & 0.005 & 0.176 & 0.018 & 0.023 & 0.006 & 0.010 & - & 0.225 & 0.148 & 0.041 \\
\hline$e$ & 0.421 & 0.789 & 0.946 & 0.615 & 0.994 & 0.950 & 0.625 & 0.775 & 0.852 & 0.959 \\
\hline$f$ & 0.287 & - & - & - & - & - & - & - & - & - \\
\hline \multicolumn{11}{|c|}{ Mdh-1 } \\
\hline$a$ & 0.099 & - & - & 0.005 & - & - & - & - & - & - \\
\hline$b$ & 0.901 & 1.000 & 1.000 & 0.995 & 1.000 & 1.000 & 1.000 & 1.000 & 1.000 & 1.000 \\
\hline \multicolumn{11}{|c|}{$M d h-2$} \\
\hline a & - & 0.007 & - & - & 0.006 & - & - & - & - & - \\
\hline$b$ & 1.000 & 0.901 & 0.946 & 0.995 & 0.964 & 0.990 & 1.000 & 1.000 & 1.000 & 1.000 \\
\hline C & - & 0.092 & 0.054 & 0.005 & 0.030 & 0.010 & - & - & - & - \\
\hline \multicolumn{11}{|l|}{ Mpi } \\
\hline$a$ & 0.064 & 0.859 & 1.000 & 0.138 & 0.786 & 0.840 & 0.100 & 0.950 & 0.481 & 0.638 \\
\hline$b$ & 0.119 & 0.049 & - & 0.014 & 0.214 & 0.020 & - & - & 0.500 & 0.362 \\
\hline C & 0.079 & 0.035 & - & 0.514 & - & 0.100 & 0.250 & - & 0.019 & - \\
\hline$d$ & 0.738 & 0.056 & - & 0.335 & - & 0.040 & 0.650 & 0.050 & - & - \\
\hline \multicolumn{11}{|l|}{ Pgm } \\
\hline a & - & - & - & 0.009 & - & - & 0.150 & - & - & - \\
\hline$b$ & 0.045 & 0.014 & - & 0.147 & - & 0.040 & 0.275 & - & - & - \\
\hline$C$ & 0.139 & 0.085 & 0.009 & 0.055 & - & 0.020 & 0.150 & - & - & - \\
\hline$d$ & 0.678 & 0.099 & 0.143 & 0.670 & 0.012 & 0.180 & 0.275 & 0.100 & - & - \\
\hline$e$ & 0.119 & 0.803 & 0.848 & 0.119 & 0.988 & 0.760 & 0.150 & 0.900 & 1.000 & 1.000 \\
\hline$f$ & 0.020 & - & - & - & - & - & - & - & - & - \\
\hline
\end{tabular}


Table 5. Pocillopora damicornis. Hierarchical analyses of molecular variance to test for differences between Ningaloo and the Houtman Abrolhos Islands reefs and between habitats for all individuals and those individuals of putative sexual origin $\left({ }^{* * *} \mathrm{p}<0.001,{ }^{\#} \mathrm{p}=0.045\right)$

\begin{tabular}{|lcc|}
\hline & All individuals & $\begin{array}{c}\text { Sexual } \\
\text { individuals only }\end{array}$ \\
\hline Among samples & $0.340^{* * *}$ & $0.160^{* * *}$ \\
within reefs $\left(F_{\mathrm{SR}}\right)$ & 0.080 & $0.084^{*}$ \\
Among reefs $\left(F_{\mathrm{RT}}\right)$ & $0.374^{* * *}$ & $0.189^{* * *}$ \\
Among samples & -0.039 & -0.034 \\
within habitats $\left(F_{\mathrm{SH}}\right)$ & $0.360^{* * *}$ & $0.175^{* * *}$ \\
Among habitats $\left(F_{\mathrm{HT}}\right)$ & & \\
Total variation & & \\
among all sites $\left(F_{\mathrm{ST}}\right)$ & & \\
\hline
\end{tabular}

tion of each to those populations sampled. Of 644 individuals sampled, only $15 \%$ was of apparently sexual origin, and samples from most sites were dominated by 1 or 2 multi-locus genotypes. This value is, however, an estimate that could be biased upwards if a proportion of asexual propagules dispersed more widely than their local source population (as hypothesised by Ayre \& Miller 2004). It may also be biased downwards in that only 6 loci were sampled electrophoretically.

The greatest impact of asexual reproduction was seen in samples from Bundegi, Winderabandi and Pelsaert Island (Sites 1, 4 and 10, respectively). In contrast, there was no indication of asexual recruitment in samples from Pilgramunna and Coral Bay (Sites 3 and 8). Both samples had high levels of genotypic diversity and conformed to single-locus equilibria. Evidence for asexual reproduction was found at the remaining sites, although its extent was variable, as shown by the large range in the ratio of observed to expected genotypic diversity values.

Notwithstanding the possibility of cryptic species, there is variation in the relative importance of asexual reproduction and in the origin of asexual recruits across the range of Pocillopora damicornis. Asexual reproduction in P. damicornis has been previously reported from populations in south-western Australia, Hawaii, the Marshall Islands, Panama and the Ryukyu Archipelago in Japan (Stoddart 1983, 1984a, Richmond 1985, Adjeroud \& Tsuchiya 1999), but not in those from the Great Barrier Reef or Lord Howe Island (Benzie et al. 1995, Ayre et al. 1997a, Miller \& Ayre 2004; but see Ayre \& Miller 2004 for evidence of asexual planulae). Although, not discounting asexual reproduction via fragmentation, the greatest contribution of asexual recruitment to populations in south-western Australia, the Houtman Abrolhos Islands, Hawaii and the Marshall Islands appears to come from brooded ameiotic planulae (Stoddart 1983, 1984a, Richmond 1985). In contrast, asexual recruitment to populations in Panama and the

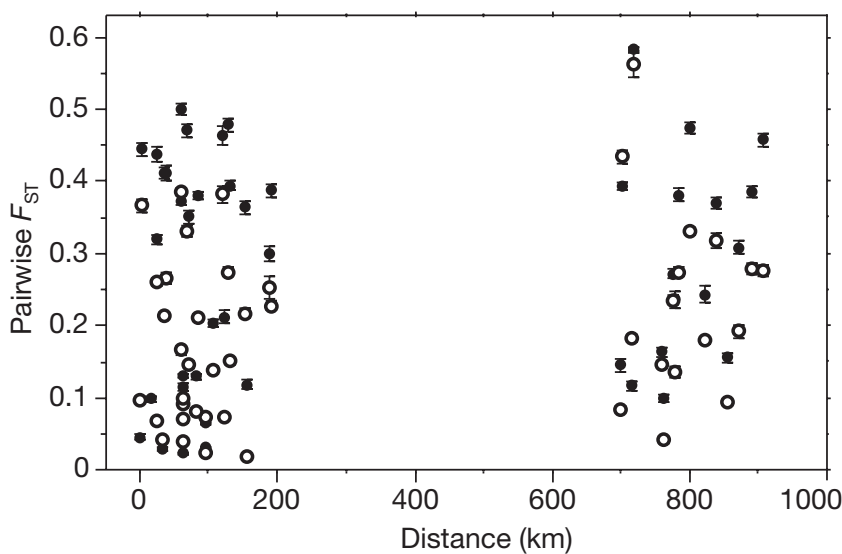

Fig. 3. Pocillopora damicornis. $F_{\mathrm{ST}}$ values (mean $\pm \mathrm{SE}$ ) between pairs of samples ( $\bullet$ all multi-locus genotypes; o: excluding replicate multi-locus genotypes)

Ryukyu Archipelago is thought to be by fragments following storm activity (Richmond 1985, 1987, Adjeroud \& Tsuchiya 1999). The frequency distribution of replicate genotypes arising from colony fragmentation is expected to be more even than ameiotically produced clones, since disturbances such as storm damage tend to have broad-scale effects (Adjeroud \& Tsuchiya 1999). On this basis it is likely that asexual recruits originate from ameiotic planulae and not fragments in northwestern Australia, since samples were dominated by only a few genotypes. Moreover, reattached P. damicornis fragments were not found during triannual monitoring of 36 permanent transects along the Ningaloo Reef over a period of $3 \mathrm{yr}$ (K. Whitaker unpubl. data).

Mixed modes of reproduction have been previously inferred from population genetic studies of taxonomically diverse marine invertebrates, including scleractinian corals, anemones, zoanthids, holothurians, gorgonian corals, starfish and soft corals (e.g. Stoddart 1983, Willis \& Ayre 1985, Johnson \& Threlfall 1987, Coffroth et al. 1992, Burnett et al. 1995, Billingham \& Ayre 1996, McFadden 1997, Uthicke et al. 1998, Adjeroud \& Tsuchiya 1999, Ayre \& Hughes 2000). Patterns similar to those found in the present study were reported, including reductions in multi-locus genotypic diversity, single- and multi-locus disequilibria and approximately equal numbers of heterozygote excesses and deficits.

Despite clear theoretical expectations from models like the Strawberry-Coral model (Williams 1975), the conditions that are thought to favour one mode over the other in marine species are still largely unknown, and presently no consistent patterns have been observed. In some species, which conform to Williams' (1975) model, sexual reproduction appears to be favoured in habitats with relatively higher levels of disturbance. Populations of the anemone Actinia tene- 
brosa on unstable boulder beaches have higher genotypic diversity values than those on stable shores (Ayre 1984), where asexual proliferation of a few locally adapted genotypes is favoured (Ayre 1985). In addition, genotypic diversity of the coral Porites compressa is highest in populations from disturbed habitats (Hunter 1993). In contrast, for some Panamanian corals (e.g. Pocillopora damicornis and Acropora palmata), habitat disturbance is responsible for high levels of asexual reproduction via fragmentation, but only when those habitats are either structured to maintain fragments or habitat disturbance is episodic followed by longer periods of relative calm sufficient for fragment reattachment to the substrate (Highsmith 1982, 1985). A third and different response to habitat disturbance has been observed in the gorgonian coral Plexaura kuna, in which sexual reproduction, as inferred by genotypic diversity, is greatest at intermediate levels of habitat disturbance (Coffroth \& Lasker 1998). Presently a general hypothesis to explain differences in reproductive effort is still under debate because of the difficulties in quantifying different types of disturbances in cross-study comparisons.

The conditions that favour one mode of reproduction over the other in Pocillopora damicornis are still unknown, but offer interesting opportunities for further research, especially given the recent finding that $P$. damicornis in eastern Australia does produce asexual planulae, but that they do not appear to recruit into the local adult population (Ayre \& Miller 2004, Miller \& Ayre 2004). If large-scale habitat disturbance plays any role, it is likely to be a minor one at Ningaloo and the Houtman Abrolhos Islands. Given the extremely skewed frequency distribution of asexually derived colonies, disturbances such as cyclones or storms are unlikely to drive mode of reproduction.

\section{Population structure}

Interpretation of Pocillopora damicornis population structure is complex. Samples from populations at Ningaloo Reef and the Houtman Abrolhos Islands have high levels of genetic differentiation that is greater within than between reefs, but is not associated with habitat type or geographic distance. Most sites share less than half their genotypes, and, although genetic subdivision among samples of $P$. damicornis is high $\left(F_{\mathrm{ST}}=0.360\right)$, almost $50 \%$ of this variation is due to differences among individuals of sexual origin $\left(F_{\mathrm{ST}}=\right.$ 0.175). Six of the sites conformed to equilibria after removal of replicate multi-locus genotypes, while the remaining sites showed significant average deficits of heterozygotes. Asexual reproduction contributes substantially to local abundance, making an otherwise rel- atively rare organism common. Of 644 colonies sampled, only 96 were estimated to be of sexual origin.

Stoddart (1984b) found very similar levels of genetic subdivision $\left(F_{\mathrm{ST}}=0.391\right)$ among Pocillopora damicornis samples from southwestern Australian reefs. He also found reductions in observed genotypic diversity and inferred mixed modes of reproduction, raising the possibility of similar mechanisms operating along the Western Australian coast. In contrast, from 2 studies on the Great Barrier Reef, 1 on Lord Howe Island reefs and 1 in the Ryukyu Islands, estimates of genetic variation among collections were much lower, although statistically significant $\left(F_{\mathrm{ST}}=0.045,0.04,0.102\right.$ and 0.056, respectively) (Benzie et al. 1995, Adjeroud \& Tsuchiya 1999, Ayre \& Hughes 2000, Miller \& Ayre 2004). As in Western Australian populations, most of the genetic variation on the Great Barrier Reef is contained within and not between reefs (Ayre \& Hughes 2000).

Significant genetic subdivision has been found among populations of 4 other coral species at Ningaloo, irrespective of life-history traits. $F_{\mathrm{ST}}$ values for the brooding corals Stylophora pistillata and Seriatopora caliendrum were 0.093 and 0.259 , respectively, and all samples were in Hardy-Weinberg equilibrium. Two broadcasting species, Acropora digitifera and A. aspe$r a$, also showed significant genetic subdivision among samples $\left(F_{\mathrm{ST}}\right.$ values were 0.010 and 0.067 , respectively) but had an average deficit of heterozygotes across all loci, supporting the view of restricted genetic mixing at both the gametic and larval stages, thus resulting in inbreeding. None of the 4 species showed evidence of asexual recruitment (Whitaker 1997, 2004). Elsewhere significant genetic subdivision has been found among corals in south-western Australia (Stoddart 1984b), the Ryukyu Islands, Japan (Adjeroud \& Tsuchiya 1999, Nishikawa \& Sakai 2003, Nishikawa et al. 2003), Taiwan (Dai et al. 2000) and the Great Barrier Reef (Ayre \& Dufty 1994, Benzie et al. 1995, Ayre \& Hughes 2000), which has also been attributed to restricted genetic mixing and a predominance of local recruitment.

The interplay of the breeding system, selection, recruitment histories and dispersal of larvae or gametes was not investigated in this study. So the inference of restricted gene flow and asexual reproduction and inbreeding among some sexually reproducing colonies should be treated as a working hypothesis. Given the high levels of genetic differentiation among samples that were maintained even among recruits of putative sexual origin and the return of most samples to equilibrium proportions following removal of recruits of asexual origin, support is provided for restricted genetic mixing as opposed to strong within-generational selection and broad-scale dispersal. The observed deficits of heterozygotes among the remaining samples of sexual 
origin may be the result of inbreeding, given the effect of asexual reproduction on local abundance. There are of course different causes of heterozygote deficits (e.g. Zouros \& Folz 1984), but until the precise reproductive origin of recruits is identified, by more sophisticated markers than allozymes, and the spatial scale of dispersal of sexual and asexual propagules is determined, the conclusions drawn from this study as well as similar studies are still tentative.

Acknowledgements. I thank M. S. Johnson for insightful comments on an earlier version of this paper, David Ayre and 2 anonymous reviewers for further improving the manuscript. Funding was provided by the Department of Zoology, The University of Western Australia, Mobil Exploration and Producing, Woodside Petroleum, Exmouth Shire, the Conservation, Animal Rescue, Research and Education group of Exmouth and Kailis Fisheries. I thank many dive buddies, Conservation and Land Management and B. Lefroy for accommodations; L. Marsh for coral identification verification; J. Stoddart for his BINOM programme; and R. Black for kindly modifying the programme to run on a Macintosh.

\section{LITERATURE CITED}

Adjeroud M, Tsuchiya M (1999) Genetic variation and clonal structure in the scleractinian coral Pocillopora damicornis in the Ryukyu Archipelago, southern Japan. Mar Biol 134: $753-760$

Ayre DJ (1984) The effect of sexual and asexual reproduction on geographic variation in the sea anemone Actinia tenebrosa. Oecologia 62:222-229

Ayre DJ (1985) Localized adaptation of clones of the sea anemone Actinia tenebrosa. Evolution 39:1250-1260

Ayre DJ, Dufty S (1994) Evidence for restricted gene flow in the viviparous coral Seriatopora hystrix on Australia's Great Barrier Reef. Evolution 48:1183-1201

Ayre DJ, Hughes TP (2000) Genotypic diversity and gene flow in brooding and spawning corals along the Great Barrier Reef, Australia. Evolution 54:1590-1605

Ayre DJ, Hughes TP (2004) Climate change, genotypic diversity and gene flow in reef-building corals. Ecol Lett 7: $273-278$

Ayre DJ, Miller KJ (2004) Where do clonal larvae go? Adult genotypic diversity conflicts with reproductive effort in the brooding coral Pocillopora damicornis. Mar Ecol Prog Ser 277:95-105

Ayre DJ, Hughes TP, Standish RJ (1997a) Genetic differentiation, reproductive mode, and gene flow in the brooding coral Pocillopora damicornis along the Great Barrier Reef, Australia. Mar Ecol Prog Ser 159:175-187

Ayre DJ, Davis AR, Billingham M, Llorens T, Styan C (1997b) Genetic evidence for contrasting patterns of dispersal in solitary and colonial ascidians. Mar Biol 130:51-61

Babcock RC, Heyward AJ (1986) Larval development of certain gamete-spawning scleractinian corals. Coral Reefs 5: 111-116

Baird AH (2001) The ecology of coral larvae: settlement patterns, habitat selection and the length of the larval phase. PhD dissertation, James Cook University, Townsville

Bak RPM, Engel MS (1979) Distribution, abundance and survival of juvenile hermatypic corals (Scleractinia) and the importance of life history strategies in the parent coral community. Mar Biol 54:341-352

Benzie JAH, Haskell A, Lehman H (1995) Variation in the genetic composition of coral (Pocillopora damicornis and Acropora palifera) populations from different reef habitats. Mar Biol 121:731-739

Billingham M, Ayre DJ (1996) Genetic subdivision in the subtidal, clonal sea anemone Anthothoe albocincta. Mar Biol 125:153-163

Black KP (1993) The relative importance of local retention and inter-reef dispersal of neutrally buoyant material on coral reefs. Coral Reefs 12:43-53

Black KP, Gay SL, Andrew JC (1990) Resident times of neutrally-buoyant matter such as larvae, sewage or nutrients on coral reefs. Coral Reefs 9:105-114

Bohonak AJ (1999) Dispersal, gene flow, and population structure. Q Rev Biol 74:21-45

Burnett WJ, Benzie JAH, Beardmore JA, Ryland JS (1995) Patterns of genetic subdivision in populations of a clonal cnidarian, Zoanthus coppingeri, from the Great Barrier Reef. Mar Biol 122:665-673

Coffroth MA, Lasker HR (1998) Population structure of a clonal gorgonian coral: the interplay between clonal reproduction and disturbance. Evolution 52:379-393

Coffroth MA, Lasker HR, Diamond ME, Bruenn JA, Bermingham E (1992) DNA fingerprints of a gorgonian coral: a method for detecting clonal structure in a vegetative species. Mar Biol 114:317-325

Dai CF, Fan TY, Yu JK (2000) Reproductive isolation and genetic differentiation of a scleractinian coral Mycedium elephantotus. Mar Ecol Prog Ser 201:179-187

Done TJ (1982) Patterns in the distribution of coral communities across the central Great Barrier Reef. Coral Reefs 1: 95-107

Duffy JE (1993) Genetic population structure in two tropical sponge-dwelling shrimps that differ in dispersal potential. Mar Biol 116:459-470

Excoffier L, Smouse PE, Quattro JM (1992) Analysis of molecular variance inferred from metric distances among DNA haplotypes: application to human mitochondrial DNA restriction data. Genetics 131:479-491

Forde MJ (1994) Ecology of the muricid gastropod Drupella cornus (Röding 1798) and its significance as a corallivore on Ningaloo Reef, Western Australia. MSc dissertation, University of Western Australia, Perth

Glynn PW, Gassman NJ, Eakin, CM, Cortes J, Smith DB, Guzman HM (1991) Reef coral reproduction in the eastern Pacific: Costa Rica, Panama and Galápagos Islands (Ecuador). I. Pocilloporidae. Mar Biol 109:355-368

Harrison PL, Wallace CC (1990) Reproduction, dispersal and recruitment of scleractinian corals. In: Dubinsky Z (ed) Ecosystems of the world. 25. Coral Reefs. Elsevier, Amsterdam, p 133-207

Harrison PL, Babcock RC, Bull GD, Oliver JK, Wallace CC, Willis BL (1984) Mass spawning in tropical reef corals. Science 223:1186-1189

Hellberg ME (1996) Dependence of gene flow on geographic distance in two solitary corals with different larval dispersal capabilities. Evolution 50:1167-1175

Heyward AJ, Stoddart JA (1985) Genetic structure of two species of Montipora on a patch reef: conflicting results from electrophoresis and histocompatibility. Mar Biol 85: $117-121$

Highsmith RC (1982) Reproduction by fragmentation in corals. Mar Ecol Prog Ser 7:207-226

Highsmith RC (1985) Floating and algal rafting as potential dispersal mechanisms in brooding invertebrates. Mar Ecol Prog Ser 25:169-179 
Hughes TP, Baird AH, Dinsdale EA, Moltschaniwskj NA, Pratchett MS, Tanner JE, Willis BL (1999) Patterns of recruitment and abundance of corals along the Great Barrier Reef. Nature 387:59-63

Hunt A (1993) Effects of contrasting patterns of larval dispersal on the genetic connectedness of local populations of two intertidal starfish, Patiriella calcar and $P$. exigua. Mar Ecol Prog Ser 92:179-186

Hunter CL (1993) Genotypic variation and clonal structure in coral populations with different disturbance histories. Evolution 47:1213-1228

Johnson MS, Threlfall TJ (1987) Fissiparity and population genetics of Coscinasterias calamaria. Mar Biol 93:517-525

McFadden CS (1997) Contributions of sexual and asexual reproduction to population structure in the clonal soft coral, Alcyonium rudyi. Evolution 51(1):112-126

Miller KJ, Ayre DJ (2004) The role of sexual and asexual reproduction in structuring high latitude populations of the reef coral Pocillopora damicornis. Heredity 92: $557-568$

Nishikawa A, Sakai K (2003) Genetic variation and gene flow of broadcast spawning and planula brooding coral, Goniastrea aspera (Scleractinia) in the Ryukyu Archipelago, southern Japan. Zool Sci 20:1031-1038

Nishikawa A, Katoh M, Sakai K (2003) Larval settlement rates and gene flow of broadcast-spawning (Acropora tenuis) and planula-brooding (Stylophora pistillata) corals. Mar Ecol Prog Ser 256:87-97

Rice WR (1989) Analyzing tables of statistical tests. Evolution 43:223-225

Richardson BJ, Baverstock PR, Adams M (1986) Allozyme electrophoresis. A handbook for animal systematics and population studies. Academic Press, London

Richmond RH (1985) Variations in the population biology of Pocillopora damicornis. Proc 5th Int Coral Reef Cong, Tahiti 6:101-106

Richmond RH (1987) Energetics, competency, and long distance dispersal of planula larvae of the coral Pocillopora damicornis. Mar Biol 93:527-533

Sammarco PW, Andrews JC (1988) Localized dispersal and recruitment in Great Barrier Reef corals: the helix experiment. Science 239:1422-1424

Schneider S, Roessli D, Excoffier L (2000) Arlequin: a software for population genetics data analysis, Ver 2.000. Genetics and Biometry Lab., Dept. of Anthropology, University of Geneva, Geneva

Selander RK, Smith MH, Yang SH, Johnson WE, Gentry JB (1971) Biochemical polymorphism and systematics in the genus Peromyscus. I. Variation in the old-field mouse (Peromyscus polionotus). Stud Genet 6:49-90

Editorial responsibility: Charles Birkeland (Contributing Editor), Honolulu, Hawaii, USA
Stoddart JA (1983) Asexual production of planulae in the coral Pocillopora damicornis. Mar Biol 76:279-284

Stoddart JA (1984a) Genetical structure within populations of the coral Pocillopora damicornis. Mar Biol 81:19-30

Stoddart JA (1984b) Genetic differentiation amongst populations of the coral Pocillopora damicornis off southwestern Australia. Coral Reefs 3:149-156

Stoddart JA (1989) Fatal attraction. Landscope 4(4):14-20

Stoddart JA, Taylor JF (1988) Genotypic diversity: estimation and prediction in samples. Genetics 118:705-711

Uthicke S, Benzie JAH, Ballment E (1998) Genetic structure of fissiparous populations of Holothuria (Halodeima) atra on the Great Barrier Reef. Mar Biol 132:141-151

Veron JEN (1986) Corals of Australia and the Indo-Pacific, edn 1993. University of Hawaii Press, Honolulu

Veron JEN (1995) Corals in space and time. The University of New South Wales Press, Sydney

Wallace CC (1985) Reproduction, recruitment and fragmentation in nine sympatric species of the coral genus Acropora. Mar Biol 88:217-233

Ward S (1992) Evidence for broadcast spawning as well as brooding in the scleractinian coral Pocillopora damicornis. Mar Biol 112:641-646

Weir BS, Cockerham CC (1984) Estimating F-statistics for the analysis of population structure. Evolution 38:1358-1370

Whitaker K (1997) Dispersal and recolonization potential of five species of hermatypic corals (Scleractinia) at Ningaloo Reef, Western Australia. PhD dissertation, University of Western Australia, Perth

Whitaker K (2004) Non-random mating and population genetic subdivision of two broadcasting corals at Ningaloo Reef, Western Australia. Mar Biol 144:593-604

Williams DMcB, Wolanski E, Andrews JC (1984) Transport mechanisms and the potential movement of planktonic larvae in the central region of the Great Barrier Reef. Coral Reefs 3:229-236

Williams GC (1975) Sex and evolution. Princeton University Press, Princeton, NJ

Willis B, Ayre DJ (1985) Asexual reproduction and genetic determination of growth form in the coral Pavona cactus: biochemical genetic and immunogenic evidence. Oecologia 65:516-525

Willis BL, Oliver JK (1988) Inter-reef dispersal of coral larvae following the annual mass spawning on the Great Barrier Reef. Proc 6th Int Coral Reef Symp, Australia 2:853-859

Wright S (1951) The genetical structure of populations. Ann Eugenics 15:323-354

Zouros E, Foltz DW (1984) Possible explanations of heterozygote deficiency in bivalve molluscs. Malacologia 25: 583-591

Submitted: July 19, 2004; Accepted: July 27, 2005

Proofs received from author(s): December 9, 2005 